\title{
Free Will Without Choice: Medieval Theories of the Essence of Freedom
}

\author{
Tobias Hoffmann \\ (Forthcoming in The Cambridge Companion to Medieval Ethics, \\ ed. Thomas Williams, Cambridge University Press, 2019)
}

Medieval authors generally agreed that we have the freedom to choose among alternative possibilities. But most medieval authors also thought that there are situations in which one cannot do otherwise, not even will otherwise. They also thought when willing necessarily, the will remains free. The questions, then, are what grounds the necessity or contingency of the will's acts, and since freedom is not defined by the ability to choose - what belongs to the essential character of freedom, the ratio libertatis. I will begin by providing the background in Augustine and in two theologians who helped transmit some core Augustinian ideas. Then I will examine a few significant accounts between William of Auxerre and William of Ockham. ${ }^{1}$

\section{Augustine and two (quasi-)Augustinians}

No one shaped discussions of free will in the Latin West more than Augustine (354-430). Two of his teachings were key for later medieval theories of free will apart from choice. The first concerns degrees of free will (libertas voluntatis, liberum arbitrium; Augustine's terminology varies): Adam, the first man, had the freedom of will to be able not to sin; but the blessed in heaven have the much greater freedom of being unable to sin. Analogously, Adam was able not to die (so long as he did not $\sin$ ); but the blessed have the much greater immortality of being unable to die (De correptione et gratia 12.33; Enchiridion 28.105; De civitate Dei 22.30). Since God and the blessed, who cannot sin, have free will, Augustine does not define it by the ability to either sin or not (Contra Iulianum opus imperfectum 6.10; cf. 5.38). And yet it is by free will that one either sins or not (e.g., De correptione et gratia 1.2 and 11.32). Thus, Augustine connects two ideas with free will: freedom from the servitude of $\sin$ (cf. John 8:31-6) and control of one's acts.

Augustine's second influential teaching is that free will is compatible with necessity, provided that what is necessary is not against one's will, such as the necessity of death (De civitate Dei

\footnotetext{
${ }^{1}$ While this article concerns medieval theories of free will apart from choice, elsewhere I discuss primarily free choice; see Free Will and the Rebel Angels in Medieval Philosophy (Cambridge University Press, forthcoming), chs. 1-5.
} 
5.10). The necessity by which the blessed can live only well and cannot sin is no threat to freedom - on the contrary, it is a "blessed necessity" that grounds "true freedom" (De perfectione iustitiae hominis 4.9). ${ }^{2}$

The impact of these ideas on later medieval thinkers was partially mediated by two theologians who were deeply influenced by Augustine (although they never cite him in their treatises on free will): Anselm of Canterbury (1033-1109) and Bernard of Clairvaux (1090-1153). Anselm insists that "the ability to sin is neither freedom nor a part of freedom"; if it were, then neither God nor the blessed angels would have freedom of decision. Anselm carefully avoids saying that anyone is free to sin. The evil angel "sinned by his decision that was free, but not on account of its being free" (De libertate arbitrii 2 ). Anselm defines freedom of decision (libertas arbitrii) as "the ability to preserve rectitude of the will for the sake of rectitude" (DLA 3 and 13). ${ }^{3}$ Most later medieval authors agree with Anselm that freedom does not consist in the ability to sin or not. ${ }^{4}$ But they prefer to define freedom of decision differently, emphasizing more the idea of control.

Bernard of Clairvaux develops central Augustinian insights in a way that allows for conceiving freedom not only as ordered to the good, but also as control. The ideas of goodness and control, however, now come apart. Bernard distinguishes three types of freedom: freedom from necessity, from sin, and from misery. He also expresses these in positive terms, as freedom of decision (libertas arbitrii), which belongs to our natural constitution; freedom of counsel (libertas consilii), which is a gift of grace and prevents freedom of decision from willing evil; and freedom of delight (libertas complaciti), which belongs to the state of glory in heaven and guarantees that freedom of decision does not lack what it wills (De gratia et libero arbitrio 3.6-7; 6.20; 7.21). Freedom of decision means to act of one's own accord (sponte), not by some foreign impulse; in fact, it is freedom from external necessity (DGLA 4.9). As for Augustine, so also for Bernard, the second and third types of freedom have degrees: being able not to sin and being able not to be distressed, as opposed to being unable to sin and being unable to be distressed (DGLA 7.21). Bernard sharply distinguishes these two types from freedom of decision (DGLA 3.6; 4.11). Contrary to Augustine, he insists that freedom of decision cannot be increased or diminished; in fact, according to Bernard it is found equally in God and in rational creatures, in the just and in sinners, in this life and in the

\footnotetext{
${ }^{2}$ For a recent study of Augustine's theory of free will, see Eric L. Jenkins, Free to Say No? Free Will and Augustine's Evolving Doctrines of Grace and Election (Eugene, OR: Wipf \& Stock, 2012).

${ }^{3}$ For more details and discussion, see Sandra Visser and Thomas Williams, "Anselm's account of freedom," in The Cambridge Companion to Anselm, ed. Brian Davies and Brian Leftow (Cambridge University Press, 2004), 179-203.

${ }^{4}$ A minority rejected Anselm's theory that freedom excludes the ability to sin, for example Peter Lombard, Sententiae 2.25.8 n. 8, 3rd ed., vol. 1:468, and most outspokenly Peter Olivi; see Bonnie Kent, "Our Inalienable Ability to Sin: Peter Olivi's Rejection of Asymmetrical Freedom,” British Journal for the History of Philosophy 25 (2017): 1073-1092.
} 
next (DGLA 4.9; 7.21; 8.24; 9.28; 9.30). Bernard adopts Augustine and Anselm's view that freedom of decision is not the power to choose between good and evil. But Bernard in point of fact disconnects freedom of decision from the good: the bad angels have freedom of decision even though they cannot choose good. What makes the will free is not that it acts well, but merely that it acts willingly (DGLA 10.35). Only the second and third types of freedom, then, are essentially ordered to the good.

\section{From William of Auxerre to Bonaventure}

Theologians in the thirteenth century or later are familiar with the ideas expounded above, in part thanks to Peter Lombard's summary discussion in book 2 distinction 25 of his Sententiae, a sort of text book which served in theology formation from the thirteenth to sixteenth centuries. William of Auxerre (ca. 1140-1231) asks in which sense free decision, which he understands as the power to choose (Summa aurea 2.10.2, vol. 1:276-7), is free. Is the freedom (libertas) of free decision absence of coercion, the ability to turn to either alternative (namely good or evil) or the ability to turn to what one wants? (Summa aurea 2.10.4, vol. 1:283.) William distinguishes between necessity of inevitability and necessity of external coercion, which allows him to understand Bernard's freedom from necessity more precisely as freedom from coercion. The freedom of free decision, then, is freedom from coercion, which unlike the other two candidates is found in everyone who has free decision (p. 284).

Theologians writing from the 1220 s to the 1240 s pick up William's question about the freedom of free decision. Philipp the Chancellor (d. 1236) discusses William's three candidates but ends up defining freedom as the ability not to be subject to a deficiency except by one's own accord (Summa de bono, vol. 1, 183-9). Hugh of St. Cher (d. 1263), the first Dominican Master, identifies freedom with the ability to do what one wants (In Sent. 2.25, ed. Riccardo Saccenti, 230). Albert the Great (ca. 1200-1280) understands freedom in one sense as the ability to turn to either alternative, in another sense as the ability to do what one wants, and in a third sense as Anselm's ability to conserve rectitude for its own sake (De homine, vol. 27/2:520b).

After William of Auxerre it becomes standard to replace Bernard's freedom from necessity with freedom from coercion and to consider free decision to be compatible with necessity of immutability. Bonaventure (1221-1274), for example, writes that God, Christ, the angels, and the blessed have free decision although they cannot will evil. Bonaventure clarifies, however, that even when willing something necessarily, free decision requires that one wills "by one's own command," 
which he explains as willing one's own willing, moving oneself to will, being one's own master in willing. In contrast, the ability to choose among alternatives is not essential to free decision as such, only to a special type of free decision, which Bonaventure calls "free decision as deliberating" as opposed to the general notion of "free decision as free" (In Sent. 25.2.1.2 co., p. 612-13). In contemporary terms, for Bonaventure a necessary condition for free decision is sourcehood (that is, being the source of one's act, which for Bonaventure involves the will's self-motion), not the ability to do otherwise.

\section{Thomas Aquinas}

Thomas Aquinas (1224/5-1274) develops a theory of free will as compatible with necessity that initially resembles Bonaventure's. There are, however, differences, which theologians of the following generation amplify. Aquinas adopts various senses of freedom, without attempting to relate them to a core idea of freedom. ${ }^{5}$

A basic assumption of Aquinas's moral psychology is that the will is a "rational appetite" (appetitus rationalis), that is, an appetitive power whose inclinations result from rational cognition. For Aquinas, this implies two things regarding the things we love (that is, the things we desire, choose, or enjoy): we can love only things in which we see some aspect of good, and we cannot help but love those things in which we see only good and no aspect of evil. Thus, according to Aquinas, we love happiness necessarily, provided we think about it (Summa theologiae 1a2ae.10.2; De malo 6 co., ed. Leonina 23:150a). (A further explanation of why we desire happiness necessarily is that our will is by nature ordered toward happiness; De veritate 22.5 co.; ST 1a.82.1.) The blessed, who have direct knowledge of God, love God necessarily, for they see that he is good from every perspective. In contrast, in this life we have only imperfect knowledge of God, and so we do not love him necessarily (ST 1a.62.8; 1a.82.2). God, too, loves himself necessarily, because his will is by nature ordered toward his essence (ST 1a.19.3). God's self-love grounds the so-called "spiration" of the Holy Spirit, that is, his procession from the Father and the Son (ST 1a.27.3-4; 1a36.2; 1a41.2 ad 3); for Aquinas and his contemporaries, spiration is another prime example of necessary acts of the will. In sum, according to Aquinas, necessary willing is rooted in the nature of the will and in the knowledge of an all-encompassing good. He occasionally expresses the root of necessity in terms of "determination," either a determination by nature (De veritate $22.5 \mathrm{ad} 2$ and ad s.c. 5) or

\footnotetext{
${ }^{5}$ See Jamie Anne Spiering, “What is Freedom?': An Instance of the Silence of St. Thomas," American Catholic Philosophical Quarterly 89 (2015): 27-46.
} 
a determination by the object known as good from every perspective (De malo 6 co., ed. Leonina 23:149b-150a).

Although these acts of the will are necessary and not subject to choice, Aquinas considers them to be free (see, e.g., De potentia 10.2 ad 5; Contra doctrinam retrahentium a religione 13, ed. Leonina 41C:64b). Augustine's De civitate Dei 5.10 is Aquinas's preferred authority in confirmation that certain kinds of necessity are compatible with the will and with freedom (e.g., De veritate 22.5 co.). Like his contemporaries, Aquinas holds that what is contrary to freedom is violence or coercion (violentia vel coactio). Violence and coercion impede a thing's natural movement; for example, throwing a stone upward is violent because it impedes the stone's natural fall. But when the will acts necessarily, its own inclination is not violated, and hence it is that we freely desire happiness, that God freely loves himself, and that the Holy Spirit is freely produced (De potentia 10.2 ad 5). Physical movements can be coerced, but the will's inclinations cannot. The will can only be moved by its own inclination, in other words, the will is always the source (principium) of its act ("sourcehood"). One cannot be coerced to will something voluntarily (De veritate 22.5 co.; ad 2; ST 1a2ae.6.4). Even the fallen angels, who immutably persist in their act of turning away from God, persist voluntarily and so are free in the basic sense of being uncoerced (De malo 16.5 ad 8). Voluntariness is in fact partly defined by freedom from coercion; in addition, voluntariness requires that a person be aware of relevant circumstances. Thus not every action that is free from coercion is also voluntary; if I shoot a passerby, ignorant through no fault of my own that someone is passing by, I do so involuntarily (ST 1a2ae.6.1-2; 1azae.6.8). The highest degree of voluntariness, which Aquinas calls "voluntariness in the perfect sense," is when one knows not only a thing that is an end (that is, worthy of pursuit), but also the reason why it is an end (ratio finis) and how certain things are ordered to the end (ST 1a2ae.6.2; cf. De veritate 24.1 co.).

In a minimal sense, then, free will is freedom from coercion; thus free will presupposes sourcehood, but not the ability to do otherwise. Aquinas usually reserves the term free will (libera voluntas, also libertas voluntatis) for this broad notion of freedom. (It is what Bonaventure calls free decision, liberum arbitrium). Alternative possibilities are required, however, by free will in the narrow sense of freedom of choice, which Aquinas calls free decision (see especially De malo 16.5 co.). (Bonaventure calls it free decision as deliberating. ${ }^{6}$ Terminological differences aside, Aquinas understands sourcehood differently from Bonaventure; for Aquinas the will's necessary acts do not

\footnotetext{
${ }^{6}$ For a more detailed account of Aquinas's general notion of free will in contrast with free decision, see Tobias Hoffmann and Cyrille Michon, "Aquinas on Free Will and Intellectual Determinism," Philosophers' Imprint 17 (2017): 136 , at $1-8$.
} 
spring from its self-motion, as Bonaventure holds, but rather from a determination, either by the will's own nature or by the intellect's cognition.

While in one sense the will is always free because it cannot be coerced, Aquinas also has a notion of freedom that requires more. According to Aristotle's teaching recalled by Aquinas, coercion in the strict sense means that the source of action is entirely outside, bare of any contribution from the one suffering coercion. This is the kind of coercion that the will cannot undergo. Coercion in a broader sense includes what Aristotle calls mixed voluntary actions, which are done under duress or from fear. When one acts under duress, one still acts voluntarily (ST 1a2ae.6.6; cf. Nicomachean Ethics 3.1.1110a4-19), but one is not fully free, for one acts not by one's will, but against it, only to avoid a greater evil (In Sent. 3.34.2.2 qc. 1 co.; Summa contra Gentiles 4.22 n. 3588). A further sense of freedom, then, is freely doing what one wants (ST 2a2ae.162.4 ad 4; De perfectione spiritualis vitae 10) - a sense considered by William of Auxerre, preferred by Hugh of St. Cher, and adopted by Albert as one of several senses.

Freedom as lack of coercion or as doing what one wants has no relation to the true good; in fact, this freedom can be experienced in search of something merely apparently good (SCG 4.22 n. 3589), and as we have seen, it is even experienced by the fallen angels who permanently reject the true good. But this is not "true freedom," for true freedom - which Aquinas also calls "spiritual freedom" - makes reference to the true good. True freedom is freedom from sin, because it allows us to tend to what suits us (ST 2a2ae.183.4 co.), freeing us from what separates us from the good (In Sent. 2.25.1.5 ad 2). Citing Saint Paul, "Where the spirit of the Lord is, there is freedom" (2 Cor 3:17), Aquinas writes that someone who turns away from the good acts slavishly, whereas the Holy Spirit, through the gift of charity, confers on a person the freedom to be inclined to the true good (SGC 4.22 n. 3589; ST 2a2ae.183.4 ad 1).

The necessity to will or do the good, then, does not threaten free will; but Aquinas says more: it enhances free will (SCG 3.138 n. 3120; ST 1a.62.8 ad 3; ST 2a2ae.88.4 ad 1). In addition to the grounds of necessity considered above, a certain necessity to do the good can result from a freely taken initiative, such as when someone is made firm in the good through virtue (SCG 3.138 n. 3120) or when someone commits to something good by means of a promise or a vow. Although such self-commitments make the corresponding acts in a sense necessary, they become thereby more praiseworthy and more meritorious (Contra doctrinam retrahentium a religione 13; ST 2a2ae.88.6). Aquinas frequently cites in this context Augustine's Epistula 127 (n. 8): "Fortunate is the necessity which compels to what is better!" 


\section{Henry of Ghent}

Bonaventure holds that the will's necessary acts result from its self-motion. Some theologians directly or indirectly influenced by Bonaventure elaborate this point. Peter Olivi (ca. 1248-1298), for example, makes the will's self-motion the most essential feature of the will's freedom and insists more strongly than Bonaventure that the will's necessary acts (e.g., our desire for happiness) are self-moved (Quaestiones in secundum librum Sententiarum 57 ad 17, ad 29, vol. 2: pp. 358-9, 378). Henry of Ghent (d. 1293), the most prominent theologian in the two decades after Aquinas's death, develops this idea systematically. Henry adopts Aquinas's terminology: only free decision (liberum arbitrium), but not free will (libertas voluntatis), requires the ability to choose among alternatives (Summa 45.3 ad 1; 45.4 co., Opera omnia 29:120, 125). For Henry, it is clear that free will is compatible with necessity. But in contrast to Aquinas, he considers free will to be incompatible with determination of any sort, whether it be determination by nature or by the intellect.

Henry explicitly draws out the implications of his theory of necessary willing for the ratio libertatis while discussing free but necessary willing regarding human freedom (Quodlibet 3.17) and, shortly thereafter and in more detail, regarding divine self-love (Summa 45-47). ${ }^{7}$ Henry gives a simple explanation of why God loves himself necessarily: the end of any will whatever is God himself, in whom there is the perfect character of every good; hence everything necessarily wants the good that is God, provided it knows him; God knows himself; so he necessarily loves himself (Summa 47.5 co., vol. 30:25).

The more crucial questions for Henry are why the divine will remains free in acting necessarily and by what kind of necessity it acts. Henry makes an important observation: considering the manner in which the will elicits its act (its modus eliciendi) is more essential to the problem of free will than considering which object its act is concerned with (Quodl. 3.17 co., ed. Badius, 78vG). Accordingly, regarding divine self-love, he clarifies that the difficulty concerns not the necessity by which God wills a determinate object, but rather the necessity by which a will-act springs forth from God's will. Manifestly, God's will-act has necessarily the divine essence as its object. But by which necessity does the act of loving his essence spring forth from his will? (Summa 47.5 co., vol. 30:25-6.) Henry excludes from the divine will the necessity imposed by something external by way of violence or coercion, for the same reason given by Aquinas: the will essentially wills from an internal inclination, and so it cannot be moved against its inclination. In confirmation, Henry

\footnotetext{
${ }^{7}$ In Quodl. 14.5, a late text, Henry takes a different approach to the ratio libertatis but fundamentally confirms his earlier account. For a discussion of this text, see Martin Pickavé, "Que signifie 'être libre'? Le cas Henri de Gand," Médiévales 63 (2012): 91-104.
} 
mentions Aristotle's statement that what is necessary due to violence is unpleasant, and he quotes Averroes's comment on this statement: "Willing [voluntas] is delightful, necessity is unpleasant." (Summa 47.5 co., vol. 30:26-7; cf. Quodl. 3.17 co., 78vG.)

But not all types of necessity are incompatible with freedom. Henry takes up the standard distinction between necessity through coercion, which derives from something external, and necessity of immutability, which arises from an internal condition. For Henry it is crucial to further divide necessity of immutability into a necessity that is antecedent to the divine will and one that is concomitant with the divine will. Antecedent necessity would submit the divine will, and this would eliminate the freedom by which it elicits its act of love. Antecedent necessity is what characterizes nature (that is, a natural cause) as opposed to the will (that is, a free cause). In contrast, the necessity by which the divine will loves God himself is concomitant to the will's act, springing from the divine will itself; and this is what matters for Henry. While antecedent necessity would submit the will, concomitant necessity is submitted to the will (Summa 47.5 co., vol. 30:27-8).

What Henry here expresses in terms of antecedent as opposed to concomitant necessity, he had expressed a few articles earlier in terms of determination as opposed to lack thereof. Determination destroys freedom because it removes agency: the inclination or direction of a determined thing has its source not in itself, but in what determines it (Summa 45.3 co., vol. 29:111). Only the appetitive power of nonhuman animals is subject to determination: their movement is determined by whatever happens to be in their perception. Thus, sheep invariably flee wolves and wolves invariably pursue sheep. In willing, nonhuman animals do not act, but rather are acted upon, as Henry writes, citing a popular phrase from John of Damascus. Hence their movement is not free, but slavish (Summa 45.3 co., vol. 29:112-17; 47.5 co., vol. 30:28). In contrast, passivity, that is, being moved from the outside, is foreign to any will, human, angelic or divine; instead, the will is only moved by itself (Summa 45.2 co., vol. 29:107-9).

Virtually no medieval theologian would hold that the divine will is determined by something external to God, but Henry insists that it is not even determined by the divine nature or the divine intellect (Summa 45.4 co., vol. 29:126). In loving himself, God's will is not led by antecedent necessity to its act, but rather freely leads itself to its act of self-love. The divine essence does not determine the will to love it, but only entices the will to lead itself to love it (Summa 46.3 ad 2, vol. 29:146-7). The concomitant necessity of God's self-love is freely self-imposed by the divine will (Summa 47.5 co., vol. 30:29-30); it results from the rigor of the will's freedom (Summa 47.5 ad 1,

\footnotetext{
${ }^{8}$ Averroes, In Met. 5 com. 6, ed. Ruggero Ponzalli (Bern: Franke, 1971), 100, commenting on Aristotle, Metaphysics 5.5.1015a26-30.
} 
vol. 30:33). But not all necessity in God is self-imposed. The necessity by which God lives springs simply from his nature; the necessity by which he knows himself springs from a determination of the intellect by its object, the divine essence; only the necessity by which he loves himself derives neither from nature, nor from a determination by the willed object, but only from the "mode of freedom" in God's will (Summa 47.5 co., vol. 30:32).

Henry draws out the implications of his account of necessary willing for the ratio libertatis. Concomitant necessity does not eliminate the freedom of the will, but rather makes it firm, because the will elicits this act "with delight and as it were by choice" (delectabiliter et quasi eligibiliter) (Summa $47.5 \mathrm{co}$., vol. 30:28). This concise formula summarizes Henry's view of the essence of freedom and its compatibility with necessity. "What belongs to the essential character of freedom, simply speaking, is not being able to will or not, as some people think, but only to will with delight [affectanter] and as it were by choice" (Summa 47.5 ad arg. in opp., vol. 30:34; cf. Quodl. 3.17 ad 1, 79rI). In accordance with Averroes's description of voluntariness we had seen above, "with delight" expresses that the will is not subject to necessity of coercion. "As it were by choice" expresses that the will is not subject to antecedent necessity of immutability, but rather acts of its own accord (sponte), that is, without being led, only leading itself to its necessary act. Henry qualifies "by choice" (eligibiliter) with the adverb "as it were" (quasi) in order to allow the ratio libertatis to apply also to free will apart from choice.

Like divine self-love, the love of God by the blessed in heaven is necessary and free in the sense just described (Summa 45.4, vol. 29:126; 47.5, vol. 30:28, 30; Quodl. 3.17 co. and ad 1, 78vG, $79 \mathrm{rK})$. In both cases, the necessity of the will's act in no way results from a determination by the intellect or by nature. Natural necessity - necessity rooted in a natural cause rather than in the will - is incompatible with the will and its freedom (Summa 45.3 ad 2, vol. 29:121). At most, natural necessity can be in a certain sense attached (annexa) to the will's act, yet without preventing the will from freely eliciting its act. This is the case with the act by which the divine will spirates the Holy Spirit (Summa 60.1 ad 4, ed. Badius 1520, 157vI-L).

Throughout his writings, Henry denies that the will is determined, that is, moved, by the desirable object. Rather, the will moves itself to its acts, including its necessary acts such as the enjoyment of the beatific vision. ${ }^{9}$ For Henry, the will moves itself not merely in some incidental

\footnotetext{
${ }^{9}$ See, e.g., Quodl. 9.5 co., vol. 13:132, 137; Quodl. 11.6 ad 2, ed. Badius, 457rO; Quodl. 12.26 co., vol. 16:152-3; Quodl. 13.11 ad 2, vol. 18:98-9, 103-4.
} 
sense, for example by moving the intellect which in turn moves the will, as some of his contemporaries hold; rather, in his view the will moves itself in the strict sense, reducing itself from potentiality to actuality. ${ }^{10}$ To be sure, this presupposes knowledge of a desirable object, but the causality of the desirable object and of the intellect presenting it - even in the will's necessary acts - is merely a "causa per accidens et sine qua non" - an incidental cause without which the will does not act (e.g., Quodl. 9.5 co., vol. 13:123; Quodl. 12.26 co., vol. 16:152-3; Quodl. 13.11 co., vol. 18:88).

\section{Godfrey of Fontaines}

The theologian most opposed to Henry's views on freedom is Godfrey of Fontaines (before 12501306?). Godfrey rejects Henry's view that the will's act is essentially caused by the will itself while knowledge of the desirable object is only a causa sine qua non. The implied assumption, that the will moves itself from potentiality to actuality, is contradictory: the will would be in act and not in act in the same respect. Instead, for Godfrey, the will's act is essentially caused by the object known as desirable (Quodl. 6.7 co., Philosophes Belges 3:152-4, 164, 170).

Godfrey shares the standard view that freedom is compatible with necessity of immutability but not with necessity of coercion. The ratio libertatis does not include being able to will otherwise, only being the cause or source (causa vel principium) of one's act, and so God's necessary love of his happiness and the necessary love of God by the blessed are free (Quodl. 8.16 co., Philosophes Belges 4:162-4). While for Henry it is the will's self-determination that is essential to sourcehood, for Godfrey it is the intellect's knowledge: free acts presuppose that one is one's own cause or source not merely "naturally" and hence without knowledge, like the free fall of a stone, nor merely by dint of knowing the thing that is an end, as nonhuman animals do, but rather as a result of knowing the thing that is an end, knowing why it is an end (ratio finis), and knowing how things that promote the end are related to it. An act of justice presupposes freedom in precisely this sense: one must do what is just because it is just, and so one must understand what is just and why it is just (ibid., p. 162). Godfrey, then, understands sourcehood in terms of Aquinas's "voluntariness in the perfect sense." Ultimately, the ratio libertatis is rooted in immateriality, for what makes it possible to know an end, why it is an end, and what promotes the end, is separation from matter (abstractio). This applies to the intellect no less than to the will, and hence both powers are equally

\footnotetext{
${ }^{10}$ See, e.g., Quodl. 10.9 co., vol. 14: 225; Quodl. 13.11 ad 3, vol. 18:125. Cf. Roland J. Teske, "Henry of Ghent's Rejection of the Principle: 'omne quod movetur ab alio movetur'," in Henry of Ghent: Proceedings of the International Colloquium on the Occasion of the $700^{\text {th }}$ Anniversary of His Death (1293), ed. Willy Vanhamel (Leuven University Press, 1996), 279-308.
} 
free (ibid., pp. 147, 155). Alternative possibilities are not required for freedom, and not even for praiseworthiness: willing something good is praiseworthy even if one cannot will otherwise (ibid., pp. 162-4).

\section{John Duns Scotus}

No one prior to John Duns Scotus (1265/6-1308) stressed so strongly the contingency of our willing, that is, our ability to will otherwise. His position is thus in stark contrast to Godfrey's account of free will, which Scotus in fact subjects to a detailed critique (Lectura $2.25 \mathrm{nn}$. 28-37, 40-50). But Scotus admits that there are cases of necessary willing which are nonetheless free. While his explanation of the compatibility between freedom and necessity is similar to Henry's, he shifts the emphasis from the psychology of intellect and will toward the metaphysics of the distinction between nature and will.

Scotus makes the novel claim that human psychology does not entail that we desire happiness necessarily and that the blessed in heaven love God necessarily (Ordinatio 1.1.2.2 nn. 143-5). To prove this claim, he postulates an axiom that one power has only one mode of originating or eliciting its acts, namely, by natural necessity or freely. In other words, a single power either elicits all its acts by natural necessity or it elicits all its acts freely. Thus, for Scotus, it is not possible that the will wills "the end" by natural necessity, but "what promotes the end" freely, as Aquinas had held (ST 1a.82.2; 1a2ae.10.2). ("The end" or "ultimate end" is in different respects God and happiness; see Aquinas, ST 1a2ae.1.8; Scotus, Ordinatio 1.1.2.2 n. 82.) Scotus argues that since it is manifest that the human will wills what promotes the end freely, it must be the case that it also wills the end freely. If this is so in this life, then it is so as well for the blessed, whose will is not different from ours; hence even the blessed will God freely (Ordinatio 1.1.2.2 nn. 80, 136). Freedom here means the ability to will the end (velle) or not (non velle). To will against (nolle) the end, however, is impossible, since the end contains no aspect of evil (Lectura 1.1.2.2 n. 118; Ordinatio 1.1.2.2 nn. 147, 149-51; Quodl. 16 nn. 20, 22, ed. Noone and Roberts).

If the will elicits its acts freely and never changes its mode of eliciting its acts, what makes the final reward and punishment eternal? Scotus's answer is that while the freedom of the blessed would allow them not to love God, God prevents them by his grace from turning away from him (Ordinatio 4.49.1.6 nn. 348-71). And while the freedom of the damned would allow them to suspend their act of evil willing (Ordinatio $2.7 \mathrm{nn} .70-5$ ), God refuses to give them the grace required for meritorious acts by which they would return to God (Ordinatio $2.7 \mathrm{nn} .51-4,60$ ). 
Scotus provides a further reason why, divine intervention aside, rational creatures do not will anything necessarily. A necessary act of the will requires three necessary and jointly sufficient conditions: the will must be infinite, for only an infinite will cannot fail to be morally right (recta) and cannot suspend its willing of the perfectly known infinite good; the object must be an infinite good; and the object must be perfectly known. Rational creatures obviously fail to meet at least the first of these conditions. But these conditions are met in the cases of divine self-love and the spiration of the Holy Spirit (Lectura 1.10 n. 26; Ordinatio 1.10 nn. 47-9; Quodl. 16 nn. 6-7, 13, 30).

Although divine self-love and spiration are necessary, Scotus argues that they are free. $\mathrm{He}$ shows this again by means of the axiom that one power has only one mode of eliciting its act. God wills creatures contingently, and since contingency implies freedom, he wills them freely. (For Scotus, contingency implies freedom, but freedom does not imply contingency. ${ }^{11}$ ) Given this axiom, since God wills creatures freely, it must be the case that he also wills his own goodness freely (Quodl. 16 n.36; cf. Ordinatio 1.10 n. 44).

Scotus's two applications of this axiom turn out to be asymmetrical: in creatures, the fact that some volitions are contingent shows that all are contingent; in God, the fact that some volitions are contingent does not show that all are contingent, only that all are free. Scotus's axiom warrants the conclusion that the human will wills everything freely, but not the stronger claim that it wills everything contingently. ${ }^{12}$ In fact, what grounds this axiom is an idea already encountered in Henry of Ghent: what primarily differentiates active powers is their mode of eliciting their acts, rather than being concerned with this or that object (Quaestiones super libros Metaphysicorum 9.15 n. 21; Ordinatio 1.1.2.2 n. 80). There are only two such different modes: eliciting naturally or freely; accordingly, there are only two most general kinds of active principle: nature and will (Q. Met. 9.15 n. 22; Quodl. $16 \mathrm{nn} .56,62)$. So the fundamentally different ways of eliciting an act are "naturally vs. freely," not "necessarily vs. contingently" (Quodl. 16 n. 40). Necessity in general is compatible with the will and its freedom; only natural necessity is not.

What does it mean, then, to will freely when one wills necessarily, albeit not by natural necessity? Scotus's answer is indebted to Henry's discussion of God's necessary self-love, which

\footnotetext{
${ }^{11}$ See Quodl. $16 \mathrm{n} .36$ and Ordinatio 1.1.2.2 n. 131. Contingency must be traced to a free power, that is, to a will, because only the will is truly a contingent cause, controlling whether it causes its effect or not (Ordinatio 1.2.1.1-2 nn. 81, 86). On one occasion, Scotus writes that contingency does not require a free power, because it can result from natural causes being impeded (Quodl. $16 \mathrm{n}$. 40). But this is no real counterexample, for as he has shown elsewhere, contingency due to impediments, without intervention of a free power, is at bottom necessity, not contingency (Ordinatio 1.2.1.1-2 nn. 84, 87).

${ }^{12}$ Most of Scotus's direct disciples in fact rejected his claim that humans will the ultimate end contingently; see Guido Alliney, "Landolfo Caracciolo, Peter Auriol, and John Duns Scotus on Freedom and Contingency," Recherches de théologie et philosophie médiévales 82 (2015): 271-300. See also Alliney’s earlier studies cited in this article.
} 
Scotus knows very well and expounds accurately, citing also Henry's formula expressing the ratio libertatis (Quodl. $16 \mathrm{nn} .42-6$ ). A natural power is determined to act, whereas the will is never determined to act, but rather determines itself to its act, even when it wills necessarily (Quodl. 16 nn. 63-4). Scotus's account of necessary but free willing is broadly in agreement with Henry's; Scotus only rejects Henry's claim that natural necessity accompanies the spiration of the Holy Spirit (Quodl. 16 nn. 52-3; Ordinatio 1.10 nn. 25-9).

It appears, then, that for Scotus, freedom is essentially to act by will, not by nature. To act by will is to act from self-determination, that is, "as it were by choice" in Henry's formula. Only in rational creatures, but not in God, does self-determination entail contingency.

\section{Peter Auriol}

A fundamentally different approach to freedom is taken by Peter Auriol (ca. 1280-1322). While Scotus attached no importance to the part in Henry's formula that identifies freedom with delight, this is the only part that matters for Auriol.

Auriol discusses the ratio libertatis primarily in connection with the love of God by the blessed. According to Auriol, for the will to love an object necessarily, it suffices that the object be infinite goodness and that it be sufficiently known. Thus, the blessed love God necessarily, but here on earth we do not love God necessarily, because we have only imperfect knowledge of God (In Sent. 1.1.8.3 nn. 122-3, 130, ed. Buytaert).

It poses not the least problem for Auriol to call the love of the blessed free. Freedom is not defined by contingency; rather, "the formal character of freedom consists in a power through an act of complacentia and delight" (In Sent. 1.1.8.3 n. 114).

Complacentia has a different meaning than the English word complacency; for Auriol, complacentia and delight mean the same thing, although with different connotations (In Sent. 1.1.7.1 n. 68; see also n. 54). Auriol's understanding of complacentia seems influenced by Aquinas, who posited a sequence of three acts of love in the sensory appetite or the will (ST 1azae.26.1-2). According to Auriol, the perception of a desirable object that is still absent already causes a certain delight or complacentia; this is the first act of love. Second, since the object pleases, one desires it. Lastly, when one attains the object, the appetite rests in it; and this rest causes delight or complacentia more fully than the first act (In Sent. 1.1.7.1 n. 51; 1.1.8.3 n. 120; 1.17.1.2, ed. Rome, 1596, p. 412bC). Most often when Auriol speaks of complacentia, he refers to this third act of love by which the sensory appetite or the will rests in a present good. In this sense, it is the love by which the lover 
is united to the loved object, an object that is suitable (conveniens) (In Sent. 1.46.2, p. 1093aA, aFbA; 1.17.1.2, p. 411bD-E); it is love of a present good that is the end, that satiates, and that offers rest (finit, satiat, et quietat) (In Sent. 1.46.2, p. 1091aF-bA).

Auriol provides a number of arguments why complacentia is the essential character of freedom. According to Aristotle, to be free is to be for one's own sake, as opposed to slaves who are for the sake of their master (Met. 1.3.982b25-6). The only act that is for its own sake is the act of complacentia; in fact: "Ask someone why he or she does whatever act, and the answer will be 'because I like it'; ask the person further why he or she likes it, and the answer will be the same: 'just because I like it'" (In Sent. 1.1.8.3 n. 114). Another argument is reminiscent of Henry of Ghent's ideas: What is formally free is opposed to what is formally violent; but what is done with displeasure (displacentia) is said to be done violently and not freely; so, by negation, an act of complacentia is formally free (In Sent. 1.1.8.3 n. 116). Freedom so understood even extends to nonhuman animals, as Auriol remarks (In Sent. 1.1.8.3 n. 120).

To further support his notion of freedom, Auriol insists on the compatibility of freedom with necessity. He argues that a power that does not control whether it acts or not is still a free power, as long as there is complacentia. In fact, God's self-love is immutable and the spiration of the Holy Spirit occurs by natural necessity, and yet these are eminently free acts because they involve complacentia. While in these acts there is necessity with freedom, in events of natural agents there is contingency without freedom; hence contingency is not part of the ratio libertatis (In Sent. 1.1.8.3 n. 118).

The fact that Auriol holds that the Holy Spirit is produced by natural necessity already indicates a fundamental disagreement with the theory expressed in the second part of Henry's formula, that the will is free insofar as it elicits its act "as it were by choice." Auriol furthermore disagrees with this part of Henry's formula, because for Auriol, freedom does not require that the will elicits its act; in fact, he holds that God's will does not elicit its act of willing at all, and yet it is free. The divine will is identical with the divine essence; hence its act is no more elicited than is the divine essence. God's willing is subsistent willing, not elicited willing that inheres in the divine essence (In Sent. 1.46.1, pp. 1087aF-1088aA). But the denial that the divine will elicits its act of willing does not diminish the freedom of this act, precisely because freedom consists simply in complacentia (In Sent. 1.46.1, p. 1088aB-D). Clearly, then, for Auriol what is most essential to freedom is which object the will is concerned with, not in which way it elicits its act, pace Henry and 
Scotus. Freedom requires that the loved object be present, causing the will to rest in it. And freedom in a sense also requires sourcehood, for by nature, complacentia cannot be imposed, but rather must be of one's own accord (spontaneus) (In Sent. 1.1.8.3 n. 133).

One may have reservations about the soundness of Auriol's arguments for identifying freedom with complacentia. ${ }^{13}$ But the claim itself is plausible: when one possesses a loved good, one is free. Auriol's notion of freedom also expresses Aquinas's notion of "true freedom," which is freedom from sin, that is, from what separates us from the good.

Similarly to Augustine and Aquinas, Auriol holds that necessity can be beneficial to the moral quality of the will: "there is greater perfection in the will when it is drawn to the good in an unchangeable way, rather than in a changeable way" (In Sent. 2.7.1, ed. Rome 1605, vol. 1:89bE).

\section{William of Ockham}

All the thinkers considered so far agree that freedom and necessity are compatible; for them, the question is only which kind of freedom is compatible with which kind of necessity. Contrary to them all, William of Ockham (ca. 1285-1347) argues that freedom is incompatible with necessity. He clarifies his theory of freedom above all in the contexts that were traditionally seen as cases of necessary yet free willing.

Using Scotus as a foil, Ockham argues that since divine self-love and spiration are necessary, they are not free acts. For Ockham, freedom is most properly defined by contingency, in the sense of having in one's power alternative possibilities, since according to Ockham this is how freedom was understood by Aristotle and other authoritative philosophers. Scotus's axiom that one power has only one mode of eliciting its acts is worthless to show that divine self-love and spiration are free; in fact, according to Ockham this axiom, which Scotus uses to argue that all acts of the will are free, could be equally used to argue that all acts of the will are necessary. Ockham furthermore denies, like Auriol, that God's will elicits any acts; so Scotus's attempt to show that God's will elicits its act is misdirected to begin with (In Sent. 1.10.2, Opera Theologica 3:335-8, 341, $343-4)$.

Ockham's own definition of freedom is "the ability by which I can indifferently and contingently posit different things, such that I can either cause or not cause the same effect, even if no difference is found outside of this ability" (Quodlibet 1.16, OT 9:87; cf. In Sent. 1.6, OT 1:501; 4.16,

\footnotetext{
${ }^{13}$ Walter Chatton (ca. 1285-1343) refutes Auriol's arguments one by one; see his Lectura super Sententias 1.10.2 nn. 4252, ed. Wey and Etzkorn.
} 
$O T$ 7:359). Ockham stresses here that in situations that allow for making a choice, it depends entirely on myself which alternative I choose.

Like Scotus - but for different reasons - Ockham thinks that we want happiness freely and that the blessed love God freely, that is, contingently. For Ockham, we can love happiness or not, and we can even will against (nolle) happiness, because we can consider happiness to be impossible (In Sent. 1.6, OT 1:503; 4.16, OT 7:350). The blessed could want God not to exist (nolle Deum) even while contemplating the divine essence, because his existence could become detestable to them if they falsely thought that God might still punish them (In Sent. 1.6, OT 1:505-6). The blessed could also hate God, because God could command them to do so, and whatever is commanded is possible (In Sent. 4.16, OT 7:352). As to the damned, their free will would allow them to suspend the act of wanting not to be punished and of hating God, for the will is free to impede every one of its own acts (In Sent. 2.15, OT 5:339-40).

Scotus held that the beatifying act of the blessed and the sinful acts of the damned are as such contingent, but that the bestowal or refusal of God's grace makes blessedness or damnation permanent. Ockham, too, thinks that their acts are as such contingent, but he goes beyond Scotus, as appears most clearly in his discussion of the permanent states of the blessed and damned angels. Ockham holds that God is the total and immediate cause of their love or hatred of God - or at least of the act by which the blessed want not to sin and the act by which the damned want not to be punished (In Sent. 2.15, OT 5:339-46; 4.16, OT 7:352). Because the blessed or damned are not even a partial cause of these acts, these acts are not free. Only acts that are not totally caused by God remain free: the evil angels are free to tempt humans or not; the good angels are free to protect humans or not (In Sent. 2.15, OT 5:344-5). According to Ockham, there is nothing scandalous in holding that God causes others to hate him: God does not sin in doing so, for God himself is not bound by any precept. In fact, he does not owe anything to anyone, and so he cannot do anything he must not do. Besides, hatred is evil only so long as it is against a divine precept. When God commands it, it can even be meritorious (In Sent. 2.15, OT 5:343, 347, 352-3). ${ }^{14}$

Ockham clarifies that those acts of the blessed or damned that are totally caused by God are necessitated, but not coerced, for their wills do not have a natural inclination toward the contrary. Furthermore, even though these acts are not caused by their own wills, it is still their wills that want them (In Sent. 2.15, OT 5:341,351).

\footnotetext{
${ }^{14}$ See Marilyn McCord Adams, "Ockham on Will, Nature, and Morality," in The Cambridge Companion to Ockham, ed. Paul Vincent Spade (Cambridge University Press, 1999), 245-72.
} 
Still, as Ockham objects to himself, it seems that if God causes the acts of the blessed, they are less free than before, contrary to what Augustine and other "saints" hold. Ockham responds by distinguishing five senses of freedom: freedom (1) from the servitude of sin, (2) from the servitude of misery, (3) from the servitude of punishment, (4) from coercion, and (5) from immutability (which is Ockham's own preferred notion of freedom: the ability to choose among alternatives). The damned lack the first three types of freedom, but have the last two types regarding those acts that are not totally caused by God. The blessed are free regarding the first four types, and actually freer than when they were on earth. Even their freedom from coercion is greater than before: on earth, only their internal acts (that is, their volitions) cannot be coerced; in heaven, not even their external acts can be coerced. As regards the fifth type, the blessed are free only as to those acts that are not totally caused by God, and so in this sense they are less free than when they were able to sin or not; yet this restriction is no imperfection (In Sent. 2.15, OT 5:349-50, 354-6; cf. In Sent. 1.1.6, OT 1:501-2).

\section{Conclusion}

The word freedom has many senses, most of which are metaphorical. Originally, freedom was a political term denoting the opposite of servitude - a word which itself came to be used mostly metaphorically. In the Latin medieval tradition, of which modern and contemporary philosophy is the heir, the primary psychological sense of freedom became free will, which only presupposes being the source of one's act. Some thinkers emphasized that sourcehood requires certain knowledge conditions; others demanded the will's self-motion. However understood, sourcehood is only a minimal condition for free will, and as such it is indifferent regarding good and evil. Medieval theologians generally affirmed also a richer notion of freedom, which makes reference to the good, such that free will increases to the extent that one acts well and attains what one desires. In both these senses, free will is compatible with necessity. Yet for the most part, medieval theologians are not compatibilists in the contemporary sense, for they generally held that moral responsibility - at least for evil - presupposes the ability to do otherwise, and hence not merely free will, but also free choice. 
Bibliography

\section{Primary sources}

Albert the Great (1951-). Alberti Magni Opera omnia, ed. B. Geyer et al. Münster: Aschendorff. Anselm of Canterbury (1938-61). S. Anselmi Cantuariensis Archiepiscopi opera omnia, edited by

F. S. Schmitt. 6 vols. Edinburgh: Thomas Nelson \& Sons.

Aristotle (1831-70). Opera, edited by the Academia Regia Borussica. 5 vols. Berlin: Reimer.

Augustine (1955). De ciuitate Dei, edited by B. Dombart and A. Kalb. 2 vols. Corpus Christianorum Series Latina 47-48. Turnhout: Brepols.

(1969). Enchiridion ad Laurentium de fide et spe et caritate, edited by E. Evans, 49-114. Corpus Christianorum Series Latina 46. Turnhout: Brepols.

(1974 and 2004). Contra Iulianum opus imperfectum. 2 vols. Books 1-3, edited by E. Kalinka ed. M. Zelzer; books 4-6, edited by M. Zelzer. Corpus Scriptorum Ecclesiasticorum Latinorum 85/1-2. Vol. 1: Vienna: Hoelder-Pichler-Tempsky; vol. 2: Vienna: Verlag der österreichischen Akademie der Wissenschaften.

(2000). De correptione et gratia, edited by Georges Folliet. Corpus Scriptorum Ecclesiasticorum Latinorum 92, pp. 219-80. Vienna: Verlag der österreichischen Akademie der Wissenschaften.

Averroes (1971), Averrois in librum $V(\Delta)$ Metaphysicorum Aristotelis commentarius, ed. Ruggero

Ponzalli. Bern: Franke.

Bernard of Clairvaux (1957-77). Sancti Bernardi opera, edited by J. Leclercq, C. H. Talbot, H. M.

Rochais. 9 vols. Rome: Editiones Cistercienses.

Bonaventure (1882-1902). Opera omnia. 10 vols. Quaracchi and Grottaferrata: Editiones Collegii

S. Bonaventurae ad Claras Aquas.

Godfrey of Fontaines (1914). Les Quodlibets Cinq, Six et Sept de Godefroid de Fontaines, edited by

Maurice De Wulf and Jean Hoffmans. Les Philosophes Belges 3. Leuven: Institut Supérieur de Philosophie.

Henry of Ghent (1518). Quodlibeta. Paris: Jodocus Badius. Repr. Leuven: Bibliothèque S.J., 1961.

(1520). Summa quaestionum ordinariarum. Paris: Jodocus Badius. Repr. St. Bonaventure, NY: The Franciscan Institute, 1953.

(1979-). Henrici de Gandavo Opera omnia, edited by R. Macken et al. Ancient and Medieval Philosophy, Series 2. Leuven University Press; Leiden: Brill. 
Hugh of St. Cher (2013). In Sententiarum II, distinctiones 24-5, ed. Riccardo Saccenti, Conservare la retta volontà: L'atto morale nelle dottrine di Filippo il Cancelliere e Ugo di Saint-Cher (1225-1235), pp. 215-32. Bologna: Società editrice il Mulino.

John Duns Scotus (1950-). Doctoris subtilis et mariani Ioannis Duns Scoti Ordinis Fratrum Minorum Opera omnia, edited by C. Balić et al. Rome: Typis Vaticanis.

(1997-2006). Opera Philosophica, edited by G. J. Etzkorn, T. B. Noone, et al. 5 vols. St. Bonaventure, NY: Franciscan Institute; Washington, DC: The Catholic University of America Press.

(2007). Noone, Timothy B., and H. Francie Roberts. "John Duns Scotus' Quodlibet: A Brief Study of the Manuscripts and an Edition of Question 16." In Theological Quodlibeta in the Middle Ages: The Fourteenth Century, edited by Christopher Schabel, 131-98. Leiden: Brill.

Peter Auriol (1596). Commentariorum in primum librum Sententiarum. Rome: Ex typographia Vaticana.

(1605). Commentariorum in secundum librum Sententiarum. Rome: Ex typographia Aloisii Zannetti.

(1952). Scriptum super Primum Sententiarum, prologue and distinctions 1-8, ed. E. M. Buytaert. 2 vols. St. Bonaventure, N.Y.: The Franciscan Institute.

Peter Lombard (1971-81). Sententiae in IV libris distinctae. 2 vols. 3 rd edn. Spicilegium Bonaventurianum 4-5. Grottaferrata: Editiones Collegii S. Bonaventurae ad Claras Aquas.

Peter of John Olivi (1922-26). Quaestiones in secundum librum Sententiarum, edited by B. Jansen. 3 vols. Bibliotheca Franciscana Scholastica Medii Aevi 4-6. Quaracchi: Editiones Collegii S. Bonaventurae ad Claras Aquas.

Philip the Chancellor (1985). Philippi Cancellarii Parisiensis Summa de bono, ed. Niklaus Wicki. 2 vols. Bern: Francke.

Thomas Aquinas (1882-). Opera omnia, iussu Leonis XIII edita cura et studio Fratrum Praedicatorum. Rome.

(1929-47). Scriptum super libros Sententiarum magistri Petri Lombardi Episcopi Parisiensis, edited by P. F. Mandonnet (vols. 1-2) and M. F. Moos (vols. 3-4). Paris: Lethielleux.

(1965). Quaestiones disputatae, edited by P. Bazzi, M. Calcaterra, T. S. Centi, E. Odetto, and P. M. Pession. 2 vols. 1oth edn. Turin and Rome: Marietti.

(1961-67). Summa contra Gentiles, edited by P. Marc. 3 vols. Turin and Rome: Marietti. 
Walter Chatton (2007-). Lectura super Sententias, edited by Joseph C. Wey and Girard J. Etzkorn. Toronto: Pontifical Institute of Mediaeval Studies.

William of Ockham (1967-89). Opera philosophica et theologica. St. Bonaventure, N.Y.: The Franciscan Institute.

\section{Secondary sources}

Adams, Marilyn McCord (1999). "Ockham on Will, Nature, and Morality.” In The Cambridge Companion to Ockham, ed. Paul Vincent Spade, 245-72. Cambridge University Press. Alliney, Guido (2015). "Landolfo Caracciolo, Peter Auriol, and John Duns Scotus on Freedom and Contingency," Recherches de théologie et philosophie médiévales 82: 271-300.

Hoffmann, Tobias (forthcoming). Free Will and the Rebel Angels in Medieval Philosophy. Cambridge University Press.

Hoffmann, Tobias, and Cyrille Michon (2017). “Aquinas on Free Will and Intellectual Determinism," Philosophers' Imprint 17: 1-36.

Jenkins, Eric L. (2012). Free to Say No? Free Will and Augustine's Evolving Doctrines of Grace and Election. Eugene, OR: Wipf \& Stock.

Kent, Bonnie (2017). “Our Inalienable Ability to Sin: Peter Olivi’s Rejection of Asymmetrical Freedom." British Journal for the History of Philosophy 25: \#\#-\#\#.

Pickavé, Martin (2012). “Que signifie 'être libre’? Le cas Henri de Gand.” Médiévales 63: 91-104.

Spiering, Jamie Anne (2015). “'What is Freedom?': An Instance of the Silence of St. Thomas,” American Catholic Philosophical Quarterly 89: 27-46.

Teske, Roland J. (1996). "Henry of Ghent's Rejection of the Principle: 'omne quod movetur ab alio movetur'." In Henry of Ghent: Proceedings of the International Colloquium on the Occasion of the $700^{\text {th }}$ Anniversary of His Death (1293), edited by Willy Vanhamel, 279-308. Leuven University Press.

Visser, Sandra, and Thomas Williams (2004). “Anselm's account of freedom.” In The Cambridge Companion to Anselm, ed. Brian Davies and Brian Leftow. Cambridge University Press. 